\title{
Note
}

\section{Unions and the Duty of Good Faith in}

\section{Employment Contracts}

\author{
Aditi Bagchi
}

\section{INTRODUCTION}

Some American scholars of law and economics have expressed dismay at the anticompetitive and illiberal body of legal doctrine that is labor law. ${ }^{1}$ Their respondents, often in other fields if not other countries, have defended unions and the laws that support them on both economic and ethical grounds. On the one hand, unions may contribute to efficient workplace governance and correct the monopsony power of cmployers in imperfect labor markets. ${ }^{2}$ On the other hand, by increasing workers' bargaining power vis-à-vis firms, unions may effectuate distributive social policies by winning workers a larger fraction of firms' surplus. By affording employees more control over their work, unions may also leave them less alienated in

1. See, e.g., Richard A. Epstein, A Common Law for Labor Relations: A Critique of the New Deal Labor Legislation, 92 Y ALE L.J. 1357 (1983); Richard A. Posner, Some Economics of Labor Law, 51 U. CHI. L. REV. 988 (1984). But see Kenneth G. Dau-Schmidt, A Bargaining Analysis of American Labor Law and the Search for Bargaining Equity and Industrial Peace, 91 MiCH. L. REV. 419 (1992).

2. For discussion of potential productivity gains, see Charles Brown \& James Medoff, Trade Unions in the Production Process, 86 J. POL. ECON. 355 (1978); and Kim B. Clark, The Impact of Unionization on Productivity, 33 INDUS. \& LAB. REL. REV. 451 (1980). For discussion of the monopsony charge, see, for example, LLOYD G. REYNOLDS, LABOR ECONOMICS AND LABOR RELATIONS 101-03 (7th ed. 1978); Daniel J. Chepaitis, The National Labor Relatians Act, NonParalleled Competition, and Market Power, 85 CAL. L. REV. 769 (1997); John A. Litwinski, Regulation of Labor Market Monopsony, 22 BERKELEY J. EMP. \& LAB. L. 49 (2001); and Ralph $\mathrm{K}$. Winter, Jr., Collective Bargaining and Competition: The Application of Antitrust Standards to Union Activities, 73 Y ALE L.J. 14, 18,27 (1963).

1881 
the production process. ${ }^{3}$ I will offer another account of the function of labor law that appeals to both efficiency and equity principles: Unions correct for the unique opportunities for bad faith in the employment relationship.

The duty of good faith is a background condition imposed on all contracts that limits the negative effects of unequal bargaining power, but its enforcement is particularly challenging in the context of most employment relationships. I will argue first that the duty of good faith is not self-enforcing between worker and firm. I will then argue that third-party enforcement is not a viable alternative. Finally, I will present unions as an institutional means by which the duty can be enforced at low cost, and compare the American and German systems as variations on that possibility. In Germany, collective bargaining remains the predominant means by which the employment relationship is regulated. By contrast, in the United States, the decline of unionism has been matched with a rise in administrative regulation. Although collective bargaining is not without its own difficulties, substantive standards are neither an efficient nor a complete response to the problems of good faith explored in this Note.

My account of the role that labor law plays in the employment relationship is consistent with other sympathetic accounts. In fact, there is substantial overlap insofar as much of the employer behavior that results in inefficient or inequitable bargains for workers can be characterized as bad faith. The argument here differs from those dominant in the existing literature, however, in two respects. First, the problem it addresses is not just economic but also legal. Evaluating the individual employment relationship from the standpoint of contract law sheds light on the dilemmas courts face in the absence of collective bargaining. The alternative to collective bargaining principles is not, after all, an unregulated labor market. All employment contracts are subject to certain universal, immutable contract rules, including the duty of good faith. The inadequacy of individual employment contracting reflects legal as well as market failure.

Understanding employment contracts as legal as well as economic instruments is more foreign to the literature than one would expect. The tools of economics do incorporate problems of interpretation, but they are incorporated as transaction costs not qualitatively different than the cost of paper; the purpose of economic analysis is to assess contractual efficiency. Political and ethical analysis of the employment relationship, on the other

3. For a discussion of the distributive and control-enhancing aims of labor law, and the ways in which they are well- and ill-served by collective bargaining, see Charles Fried, Individual and Collective Rights in Work Relations: Reflections on the Current State of Labor Law and Its Prospects, 51 U. CHI. L. REV. 1012 (1984). For a broad overview of the advantages of collective bargaining, ranging from productivity gains to cross-class and interworker redistribution, see RICHARD B. FREEMAN \& JAMES L. MEDOFF, WHAT DO UNIONS DO? (1984). 
hand, ultimately appeals to fairness-for example, in the form of norms about control, distributive justice, or property rights. No commentator can be fairly assigned to one camp or the other, since no argument that fails to address both fairness and efficiency is plausible. Torn between two isolated principles, observers can do little more than strike an (ultimately subjective) balance between these competing values. The advantage of a selfconsciously legal analysis, focused on the challenges posed by employment contracts from the perspective of lawyers, is that these values have already been incorporated into a single framework: the common law. For example, these values are two interpretive aspects of the duty of good faith, which cannot properly be understood without reference to both. ${ }^{4}$ Although the common law no longer governs many terms of employment, due to both collective bargaining and an array of employment legislation, it nevertheless provides a useful framework by which to assess the difficult task any alternative legal regime must perform.

My second departure from prevailing accounts lies in an attempt to assess the interaction between an inequality of bargaining power, on the one hand, and information and monitoring costs, on the other. Bargaining power is an important part of the story behind the intervention of labor law, but it is only part of that story. It interacts with other features of the employment relationship to complicate workers' capacity to protect their interests on an individual basis. Standing alone, the consequences of bargaining-power disparity are not obvious; although all else equal it will result in a less equal distribution of the gains of trade, the weaker party's loss could be offset by her (albeit small) share of transaction-cost savings. If employers and employees were equally invested in each other, they would be situated in a bilateral monopoly. This normally results in high bargaining costs because each party knows that the other cannot easily go elsewhere. In the employment context, however, workers cannot afford to hold out inefficiently and prolong negotiations about each exercise of discretion by the employer that the worker considers a modification of the original contract. Unequal bargaining power means less bargaining, and where bargaining is costly, workers' absolute share of transaction-cost savings may offset a decline in their relative share of total gains from the employment contract. Clear legal allocation of discretion to the employer

4. Although lawyers may emphasize one value over the other, every legal argument implicitly acknowledges the other. For example, no one suggests that there should be an exception to the duty of good faith because the law would be more efficient without it, or cven that the violation of good faith can be legitimatcly offset with other gains. Because the concept of good faith incorporates efficiency concerns, one can more palatably argue for a more correct application of good faith or, at most, an alternative conception of good faith. Similarly, those concerned with the equitable purposes of the duty of good faith must attend to the efficiency consequences of whichever rule they propose. 
may have the sanguine effects associated with bright-line property entitlements (as opposed to fuzzy entitlements protected by liability rules).

Unequal bargaining power may also reduce transaction costs and underinvestment by workers and employers if discretion and penalties are specified contractually at the outset. Some commentators suggest that parties can anticipate attempts to renegotiate or shirk by allocating all discretion to one party and providing for a positive default level of trade or employment. ${ }^{5}$ Workers may underinvest or demand renegotiation if, as a result of employer exercise of discretion, their returns to investment (effort, years, training) decline over time. If their contract, however, guarantees them some default "average" employment terms, they are more likely to invest-in the event of employer abuse, they can invoke those inflexible terms. Employers have incentive to agree to such defaults, even where they have all the bargaining power, as a mechanism to reduce shirking. Although the background problem of shirking recognizes that effective monitoring is impossible, this model of efficient bargaining inequality presumes that parties are able to specify efficient and enforceable default terms.

A final benefit of bargaining-power disparity may result if employer discretion increases production quality and flexibility; workers' wage gains may eventually reflect their increased marginal productivity. While this implies that workers would voluntarily curb their demands even if they had bargaining power, they might not if their short-term loss was certain while their wage gains depended on other workers similarly cooperating. The concentration of decisionmaking in the employer resulting from its bargaining power could effectively resolve a collective action problem among workers.

The indirect effects of unequal bargaining power therefore complicate its aggregate effect on workers' returns. But its indirect effects do not all lower transaction costs. The costs of information gathering and monitoring are actually greater in the face of an imbalance in bargaining power. Moreover, the costs are more likely to be borne by workers because of this imbalance.

In the following discussion, I introduce a number of stylized assumptions about the labor market. Not all labor markets are characterized by the imbalance of bargaining power and high transactions costs discussed

5. Phillipe Aghion et al., Renegotiation Design with Unverifiable Information, 62 ECONOMETRICA 257, 276 (1994). Aghion and his coauthors contrast their argument with that of Oliver Hart and James Moore, who found that, in the absence of specific performance, underinvestment will result. Oliver Hart \& James Moore, Incomplete Contracts and Renegotiation, 56 ECONOMETRICA 755 (1988). The employment relationship is inhospitable to specific performance; firms cannot be forced to employ workers. But if employer and employee were able to specify efficient damage awards, these would serve as adequate security for employee investment. Their inability to specify these damage awards cannot be traced to bargaining inequality alone. 
here. The costs of information and monitoring vary and are not always borne by the employee. For example, law students working at corporate law firms are provided with information few workers could assemble on their own. And at least when they start, entrants into the law job market appear to enjoy substantial bargaining power. It is not surprising, then, that law students do not organize themselves into unions. ${ }^{6}$ The same is true to varying degrees of most professions. When employers invest in individual employees and employees are mobile-due to high skills, tight labor markets, or a strong social wage (government-provided safety net)-much of the argument does not apply.

In the labor markets I have in mind, employees' work products are fairly homogenous and a single firm employs a large number of people engaged in similar work. This applies to much of the manufacturing sector and a significant portion of the low-skilled service sector. In these labor markets, nonunionized workers are "price takers"-employers can always find ready substitutes at their named price. Under these conditions, workers do not have a credible threat of exit for any but the grossest of employer abuses; they lack credible, graded threats with which they can respond to lesser violations. ${ }^{7}$ These are essentially the markets in which unions have historically been active. The argument here is intended to explain the role that unions play and may be used to predict which markets will be most receptive to unionization; I am not making any empirical claim about the proportion of the total work force to which these assumptions apply. ${ }^{8}$ But I expect that the duty of good faith is self-enforcing in those markets in which these assumptions do not apply, and as expected, unions have the least market presence in these sectors.'

6. One could argue that a career develop:nent office is a quasi-union that does everything but bargain for you. Bargaining is an essential function of a union, but state bar associations may serve as cartels that advance the same interest in raising the price of legal work.

7. See infra Section II.B.

8. This population is likely to constitute a majority of the work force, although the ratio of high-skilled manufacturing jobs to low-skilled service sector jobs within this class is probably declining. Regardless, for the sake of exposition, I refer to the type of employment relationship I have in mind as "the" employment relationship.

9. This functionalist claim cannot be tested, because this phenomenon is presently explained by "artificial" legal limits to the applicability of collective bargaining rules. See National Labor Relations Act § 2(2)-(3), 29 U.S.C. \$ 152(2)-(3) (2000) (excluding certain categories of employers and employees). These legal limits, though, reflect Congress's understanding of the role of unions and their suitability to various labor markets. The exclusion of most professional and supervisory employees, who usually enjoy substantially greater market power, is consistent with the corrective purpose identified here. 


\section{THE ABSENCE OF SELF-ENFORCEMENT IN INDIVIDUAL EMPLOYMENT CONTRACTS}

The opportunity for bad faith and the duty of good faith go together. There is no need to impose a legal duty of good faith where there is no opportunity for bad faith. If we are playing baseball, I will follow not only the rules enforced by the umpire but also various other rules to which we would have agreed had we discussed them beforehand-such as no punching in the locker room. The umpire will not enforce this last rule because first, not anticipating my violent nature, you failed to bargain on this point; second, the umpire is not there. One of the best reasons for me to stick to this unwritten rule anyway is that you have a bat. Since I have a bat too, it is unlikely that either of us will act in "bad faith" and depart from implicit rules of the game. But if I do not have a bat, I should be concerned that the unwritten rules will shift in your favor; that is when I worry about your faith. ${ }^{10}$

The opportunity for bad faith and the duty of good faith are products of incomplete contracts. At least in the context of labor, gaps reflect high transaction costs and asymmetric information. The transaction costs are of two types: ex ante, the cost of gathering information and, ex post, the cost of monitoring agents. Both sides of a labor contract are subject to these costs, but their costs are not symmetrical and so neither are the remaining gaps. Three factors therefore complicate the effects of disparatc bargaining power: information costs, monitoring costs, and asymmetric information.

\section{A. Information Costs}

Although each party gathers some information about the other prior to entering into an agreement, employers are in a better position to gather relevant information than are employees. Employers, especially large ones, are repeat players in the bargaining of employment contracts. They often have streamlined processes for evaluating job candidates, their qualifications, and references.

10. Although this faith sounds like forbearance, the two are not always easy to separate. The general point is that symmetry is usually an essential background condition for noncoercive cooperation and the success of self-enforcing norms. While close personal relationships may not require strict equality, the most celebrated class of public norms may be those between neighbors, and, there, mutual background threats are the stuff of civic friendship. See Edward B. Rock \& Michael L. Wachter, The Enforceability of Norms and the Employment Relationship, 144 U. PA. L. REV, 1913, 1930 (1996) (arguing that the conclusions about norms in Shasta County presented in ROBERT Ellickson, ORDER Without LaW: How NeIGHBORS SETtLe DisPUTES (1991) cannot be generalized, because parties must have the power to administer sanctions for norms to be sclf-sustaining). 
Job applicants, on the other hand, especially for low-paid work, are rarely in a position to research the firm and its employment practices. The few who have the time and resources to expend on such search costs have limited access to information relevant to their future job and salary prospects, and, even then, like the aggressive consumers who read the fine print, are too few in number to affect the standard contract offered by the firm. ${ }^{11}$ Their misinformation surrounding the legal default rules governing the employment relationship suggests that job applicants can accurately assess neither the points on which bargaining is possible nor the contract areas in which negotiation is desirable for them. ${ }^{12}$ In fact, their own preferences about the implicit trade-offs among wages, work hours, and job security in their compensation packages are contingent on facts about the operations and assets of the firm and the future of its product markets. Although the employer also has limited information about the future of the firm and the skills and motivation of applicants, it is more capable of researching this information, more aware of the types of problems that recur, and more empowered to demand contract provisions that protect it (i.e., allow for monitoring and exit). ${ }^{13}$ If the asymmetry were such that ex ante information costs disproportionately fell on the firm, it might transfer this cost to the worker through contract. But the worker cannot transfer her disproportionate burden to the employer. The contract gaps resulting from information gaps therefore work disproportionately to the disadvantage of the worker, which is to say the employer gets more discretion. ${ }^{14}$

11. See Victor P. Goldberg, Institutional Change and the Quasi-Invisible Hand, 17 J.L. \& ECON. 461 (1974).

12. See Pauline T. Kim, Bargaining with Imperfect Information: A Study of Worker Perceptions of Legal Protection in an At-Will World, 83 CORNELL L. REV. 105, 133 (1997). For example, Kim's survey indicated that the average score on questions regarding the legality of various grounds for discharge was fifty-one pereent, whereas random selection would have resulted in a score of fifty percent. Id. Cass Sunstein suggests that setting default rules that favor employee interests will induce employers to raise bargaining issues. See Cass R. Sunstein, Human Behavior and the Law of Work, 87 VA. L. REV. 205, 231-32 (2001). Indeed, the legal regime to which the NLRA responded was riddled with "sticky" pro-employer default rules, and so we have no experience with the legal rules Sunstein advocates. See John Fabian Witt, Rethinking the Nineteenth-Century Employment Contract, Again, 18 LAW \& HIST. REV. 627 (2000). In the absence of a union, however, no negotiation takes place. Where the employer unilaterally outlines the conditions of employment, she will systematically contract around unfavorable default rules. Nevertheless, pro-employee default rules at least would force employers to claim discretion explicitly in various cases.

13. Although job applicants may be aware of the kinds of issues that arise in their line of employment, their information is less tailored to the job and firm they are entering.

14. The employer's advantage comes not only from its informational advantagc, but also from the fact that joint ignorance, combined with bargaining power disparity, results in discretion that determines the outcomes of situations neither party anticipated. This does not suggest that complete surprises are routine in employment, but only that even where the general types of issues are known, it is costly to learn which ones are the most likely to arise and to negotiate terms for each contingency. 


\section{B. Monitoring Costs}

Monitoring under individual employment contracts is also skewed. Employees are widely regarded as agents of a firm partly because they are treated as agents; they are monitored and expected to behave in the best interests of their principal. Firms have established mechanisms for monitoring the performance of their agents and, in most cases, retain the power to punish or fire an agent who does not perform up to par. Although there is considerable room for invisible abuse of discretion by workers (for example, reduced effort), the fact that there are many similarly situated workers on site allows the employer to compare performance. To take advantage of the discretion workers retain in their contracts, they need to work together: If everyone is lazy, the manager cannot separate the lazy from the hardworking, or even develop a standard by which to determine that everyone is lazy (relative, we assume, to workers outside that firm). Classic collective action problems, however, check this opportunity for bad faith on the part of workers, although laziness norms may evolve and impose some social costs on deviants.

Firms are not generally treated as agents of workers. But they could be. Although the performance in which workers are most immediately interested is payment of wages, they are willing (or forced) to defer wages or convert them into other goods, such as income security, quality of work and work life, future wage earnings, and benefits (especially pensions). They have extremely limited ability to monitor how well the firm serves these interests. For example, firms could pay dividends or raise management salaries rather than reinvest deferred wages in the firm, even though workers may have accepted lower salaries and benefits with the expectation that their jobs would be more secure in the future, or that their wages would increase when new technology raised marginal productivity. Similarly, in the absence of other intervening laws, firms could invest pension funds in high-risk ventures. ${ }^{15}$ To the extent that employees are reluctant to defer wages in light of their inability to monitor employers, the gains of otherwise productive exchanges are lost. To the extent that workers are forced to accept such bargains, they bear the risk of bad faith agency on the part of the firm.

Individual workers are also unable to enforce action against abuse of discretion where they can observe it, as in the context of work assignments, wage increases, and the treatment of other employees. They cannot enforce implicit boundaries to discretion because they do not have graded threatsworkers can leave the firm, but to retaliate effectively in any less drastic form, they must make the loss to the firm clear to its managers and thereby

15. See infra notes 68-72 and accompanying text. 
attract retaliation against themselves. Asymmetric monitoring and enforcement capabilities reinforce the opportunity for bad faith on the part of firms.

\section{Asymmetric Information}

The transaction costs discussed so far, including the cast of learning about one's contract preferences and implementation, apply to both parties but are disproportionately borne by workers. Workers also suffer from asymmetrical information that they acquire cheaply (without special effort) but that the employer does not have. If the employer comes to know the value some workers attach to a given benefit, she may be able to extract rent for it - that is, to appropriate a higher proportion of the net gains from the employment contract. This would not be true in a perfectly competitive market, but it holds where the employer can reduce wages by more than the marginal cost of providing the benefit. ${ }^{16}$ More generally, "[t]he separation of market power and information between two contracting parties creates powerful incentives for strategic contractual behavior."17 Deceptive signaling intended to cause the employer to mistake one for a "good worker" rather than a "bad worker" leads to inefficient pooling. For example, workers likely to become pregnant will hide their type by appearing indifferent to maternity-leave policy, resulting in pooling around an artificially low preference. ${ }^{18}$ Where the preference has to do with providing for a contingency that the default contract does not address at all, the worker will be left to bargain with the employer when it arises, at which time the employer has ultimate discretion as to what policy it will adopt. Information asymmetries thus combine with an imbalance of power to produce an inefficiency that operates to the systematic disadvantage of employees. ${ }^{19}$

16. See, e.g., Jason Scott Johnston, Strategic Bargaining and the Economic Theory of Contract Default Rules, 100 YALE L.J. 615 (1990). In Johnston's main example, based on Hadley v. Baxendale, 156 Eng. Rep. 145 (Ex. 1854), the seller engages in price discrimination against high-value buyers. Here, the employer as purchaser of labor engages in reverse price discrimination against the worker as seller. Although employers would offset benefits against wages in a perfectly competitive market, they could not extract rent.

17. Ian Ayres \& Robert Gertner, Strategic Contractual Inefficiency and the Optimal Choice of Legal Rules, 101 YALE L.J. 729, 763 (1992).

18. See Phillipe Aghion \& Benjamin Hermalin, Legal Restrictions on Private Contracts Can Enhance Efficiency, 6 J.L. ECON. \& ORG. 381, 402 (1990).

19. In the maternity-leave example, workers lose out only if the maternity leave "missed" as a result of the inefficient policy outweighs worker gains elsewhere in the contract that employers would not have conceded if they had known the real numbers expecting to take maternity leave. The employer might actually insist on granting less maternity leave per worker if it were aware of the actual number of workers expecting to use it. On the other hand, if we assume that the number of workers who get pregnant per year is constant, then employers already know how many workers will take maternity leave, and the relevant preference is how much maternity leave workers want, which is also a preference workers will have no incentive to reveal honestly. Like 
Employer market power may not only repress worker information but also warp workers' estimation of facts better known to the employer. When workers believe that employers have superior information regarding the probability of a contingency, they may interpret employer willingness to insure against it as evidence of its unlikelihood..$^{20}$ For example, if an employer offers severance pay, the worker may suspect that the employer does so in order to reduce wages at low cost and may refuse any such terms. Here, too, the combination of bargaining power disparity and asymmetric information causes incomplete contracting.

Despite these gaps, thanks to the discretion assigned to employers, employment contracts would be obligationally complete if unconstrained by a duty of good faith - the legal rights of each party would be clear. ${ }^{21}$ The employer could impose any condition on the employment relationship that was not explicitly contradicted by the original agreement. But in the absence of a duty of good faith, the employer's exercise of discretion will not necessarily maximize joint gains from the employment contract, and this makes the contract insufficiently state contingent-it does not allocate resources most efficiently in all possible states of the world. The duty of good faith therefore corrects state-contingent incompleteness at the expense of obligational completeness: Because the duty is ill-defined, ${ }^{22}$ contracting parties cannot always be sure what is legally required of them, but if they stay within its vague boundaries, they will increase their joint payoffs. The cost of this obligational incompleteness is the cost associated with having a third party attempt to clarify contractual obligations, and often get it wrong. So long, however, as the duty is self-enforcing, parties can retain the payoffs of contingent completeness without bearing the costs associated with obligational incompleteness.

Unfortunately, where discretion is not bargained for but follows from skewed information and monitoring capabilities, good faith is not selfenforcing. These asymmetries, and the underlying disparity in bargaining power, render general contractual duties of good faith inert in the context of individual employment contracts. One might expect that good faith would nevertheless be self-enforcing given the background threat of external enforcement. But fear of third-party enforcement constrains the employer

the original example, this assumes that a prospective employee cannot realistically respond to an unattractive maternity-leave policy by simply finding another job. If workers likely to get pregnant do go clscwhere, the number of workers taking leave would not be an independent variable.

20. Joseph E. Stiglitz, The Design of Labor Contracts: The Economics of Incentives and Risk Sharing, in INCENTIVES, COOPERATION, AND RISK SHARING 47, 64 n.6 (Haig R. Nalbantian ed., 1987).

21. Obligational completeness and state-contingent completeness are defined in Ayres \& Gertner, supra note 17 , at 730 .

22. See infra Part III. 
only when litigation is a credible threat. Because third-party enforcement of the duty of good faith in the employment context would be inconsistent and costly, the employer knows it is a high-risk strategy for the worker. I explain next why court enforcement has these characteristics.

\section{THE IMPOSSIBILITY OF THIRD-PARTY ENFORCEMENT IN INDIVIDUAL EMPLOYMENT CONTRACTS}

Third-party enforcement of the duty of good faith requires a coherent articulation of that duty. Unfortunately, consensus has not materialized around any single coherent articulation. ${ }^{23}$ The Restatement (Second) of Contracts places the "Duty of Good Faith and Fair Dealing" under "Considerations of Fairness and the Public Interest." ${ }^{.24}$ Each of the distinct interpretations of the duty of good faith described below incorporates both equity and efficiency concerns, but the "equity interpretation" is motivated primarily by considerations of fairness, while the "efficiency interpretation" is motivated primarily by the effort to maximize aggregate utility. Neither focus generates a viable standard to which employment contracts can be held. In order to demonstrate the difficulties associated with each, I first distinguish them from one another.

\section{A. Equity}

The equity interpretation defines bad faith as the manipulation of a contract by one party contrary to the original intent of the other. ${ }^{25}$ This position can be characterized as a "fairness argument" rather than an "efficiency argument" because it concerns the frustrated expectations of one party and not the aggregate economic effects of a contract. Nevertheless, bad behavior thus defined creates inefficiencies in the long run because, in order to protect themselves, parties will seek to specify more precisely the boundaries of discretion in future contracts, even where specification is expensive and results in costly inflexibility. But these inefficient ex ante incentives are only relevant where the worker has the

23. Introducing his own four-part test, then-Judge Souter pointed out that inconsistent application could explain "why the commentators despair of articulating any single concept of contractual good faith, even after the more than fifty years of litigation following in the wake of the American common law's first explicit recognition of an implied good faith contractual obligation." Centronics Corp. v. Genicom Corp., 562 A.2d 187, 191 (N.H. 1989). In an article exploring how common-law principles can deter opportunism, Timothy Muris avoids the principle of good faith for this reason. Timothy J. Muris, Opportunistic Behavior and the Law of Contracts, 65 MINN. L. REV. 521 (1981).

24. RESTATEMENT (SECOND) OF CONTRACTS $§ 205$ (1981).

25. For an early statement and application, see Kirke La Shelle Co. v. Paul Armstrong Co., 188 N.E. 163,167 (N.Y. 1933). 
power to insist on boundaries in future dealings-that is, where the worker normally retains something she could exchange for clearer boundaries. The original intent standard will not promote efficiency in every application.

We can best appreciate the purpose animating the original intent standard in light of its application outside of the context of good faith. The equitable doctrines of unconscionability and quasi-contract make clear that the original intent standard will not always promote the cause of efficiency. In contract renegotiation cases, the doctrine of good faith, by precluding modifications that have no purpose but to transfer wealth from one party to the other, reduces uncertainty that could otherwise dampen future contract activity. But the rule of unconscionability serves no comparable efficiency goal. Unconscionability does not preserve efficient ex ante incentives; it guards against contract terms to which informed parties under fair bargaining conditions would not agree anyway. Since the doctrine applies to contracts where one party really did not know what he was doing, the probability of a bad bargain is not relevant to future parties. Nor does the doctrine effectively deter individuals from attempting to strike unconscionable bargains, since there is some chance that they will get away with it, and if not, they can always abandon the contract rather than pursue their contractual claims in court. Efficiency does not explain the doctrine. A court that evokes unconscionability is motivated by its equity concerns on behalf of the particular persons involved in a given case.

The quasi-contract principle is likewise motivated by equity concerns. The prospect that a court will attribute contractual intent to incapacitated individuals who receive critical goods or services may reassure some who would otherwise refuse to assist anyone unable to contract expressly, and this enhances ex ante incentives. But the principle also directs courts to lower costs on a vulnerable party who has promised too much (as in the case of a stranded skier who promises to give away her first child in return for a ride to the nearest lodge), and this does not enhance incentive to contract (since the vulnerable party has no choice). Here, though, one might argue that the quasi-contract principle enhances ex post or allocative efficiency-for example, if the surcharge for rescue (above the price of rescue expected in a competitive market) is worth more to the purchaser than the seller. That is, if the rescuer charged the skier $\$ 150$ for a rescue that would cost $\$ 50$ in a competitive market, we might refuse to enforce the transfer of the full $\$ 150$ on the grounds that the skier may value the $\$ 100$ differential more. One might also argue that the principle enhances efficiency in a broader sense by preventing overdeterrence from risky activities. In general, rules motivated by equity frequently coincide with the 
best long-term strategies. ${ }^{26}$ Nevertheless, these consequentialist benefits of quasi-contract seem peripheral to its purpose in application; the language of quasi-contract focuses on the interests of equity. Positioning itself in the doctrinal family of unconscionability and quasi-contract, the equity interpretation of good faith likewise seeks to capture the unexpressed object of mutual agreement under fair bargaining conditions. ${ }^{27}$

\section{B. Efficiency}

In contrast to the equity interpretation, the efficiency interpretation borrows from Kaldor-Hicks efficiency criteria to define bad faith as an exercise of discretion that harms one party more than it benefits the other. ${ }^{28}$ This promotes one-shot efficiency (at least) because it maximizes the gains (or minimizes the losses) resulting from a single action. Attention to efficiency also advances equity insofar as such behavior betrays unreasonable indifference to the interests of others, but the language of what I here label the efficiency interpretation suggests primary concern for the sensibility of individual business transactions. Judicial interpretation that gives effect to the efficiency conception of good faith will disallow exercise of discretion by one party that results in more harm to one party than could be justified by gain to the other. Needless to say, this conception

26. This point is a common one in game theory, especially amongst repeat players in small groups. It echoes the idea implicit in truisms like "honesty is the best policy."

27. More so than in questions of good faith, the agreement the court seeks to identify in quasi-contract cases is only hypothetical. After all, a "quasi-contracrual obligation is one that is created by the law for reasons of justice, without any expression of assent and sometimes even against a clear expression of dissent." ARTHUR LINTON CORBIN, CORBIN ON CONTRACTS $§ 1.20$, at 64 (Joseph M. Perillo ed., 1993).

28. To be Kaldor-Hicks efficient, it need only be possible that the gainer compensate the loser. The efficiency interpretation is cffectively the same as a rule that prohibits exercise of discretion that harms the other party but does not benefit oneself. If $A$ has formal discretion to inflict a loss $x$ on $B$ in order to gain $y$, and $x>y$, then we will expect $B$ to offer $A$ at least $y$ to avoid the harmful behavior. The question is whether $A$ can threaten to inflict the loss anyway, to extract some sum closer to $x$ than $y$, where $x$ is substantial and was unanticipated. Despite the equivalency, the principle stated in this alternative form appeals not only to efficiency, but to equity as well, because $A$ clearly is acting opportunistically. Hence Mark Gergen labels the no gain, no harm interpretation of good faith "the principle of unselfish performance" and sees the doctrine as essentially motivated by fairncss considerations. Mark Gergen, $A$ Defense of Judicial Reconstruction of Contracts, 71 IND. L.J. 45, 46 (1995). The form I use, however, captures the broad scope of the principle in light of probable postcontract transactions.

The principle articulated by Steven Burton is also effectively the same as the efficiency principle stated here. Steven J. Burton, Breach of Contract and the Common Law Duty To Perform in Good Faith, 94 HARV. L. REV. 369 (1980). Burton argues that the duty of good faith proscribes behavior that was foresworn at the moment of contract. But the parties would presumably only foreswear conduct that produced net loss. Although he grounds this principle in respect for the expectations and intent of the contracting parties, surely a party who thought she was giving up an opportunity in exchange for the benefits of the contract would not be held to that pessimistic expectation if it turned out that it was compatible with the expectations of the other party. Seizing an opportunity once foresworn is only relevant insofar as it actually affects the other party. 
of good faith is ambiguous because it raises many questions about how to assess the value or harm of particular acts and how to isolate a single instance of discretion to which a legal rule could be applied. But it serves as a general guideline: To abuse discretion allocated by a contract is to commit acts that are very costly to the other party and result in minimal benefit to oneself. Were the circumstances anticipated at the time of contract (e.g., were information perfect and cheap), the agreement reached would have explicitly disallowed such behavior. The efficiency interpretation is similar to the equity interpretation in its retroactive proceduralism, but it emphasizes a different kind of normative underpinning for the principle of good faith.

Despite the plausible purposes behind both the abstract equity and efficiency interpretations of the good faith standard, neither can be applied coherently in the employment context.

\section{Interpretive Incoherence}

Under the equity interpretation, one party cannot use its discretion in a manner to which the other party would not have originally agreed. Under the least demanding version of this standard, a party cannot predictably lose money from the bargain (as a whole) as a result of discretionary acts by the other. A slightly more strict equity interpretation of good faith will exclude profit-annulling discretionary behavior; each party must enjoy some (any) fraction of the gains of trade from the overall bargain. ${ }^{29}$ In contrast to the lowest standard, one would not have to show positive harm or damages to prove bad faith. A still more rigorous standard of equitable good faith demands that each party's share of the gains resemble the share she could have obtained elsewhere on the market. These accounts of the good faith standard are equitable in that the imposed limits to discretion are the assumed limits of reasonable consent.

The equity standard is of limited use in the employment context due to the disparity in bargaining power. ${ }^{30}$ It is difficult to know to what an

29. This standard apparently is not prohibitively strict; it is no more constraining than an attempt to apply terms the parties would have agreed to had they bargained on the issue in question. For examples of the latter approach, see Wis. Real Estate Inv. Trust v. Weinstein, 781 F.2d 589, 593 (7th Cir. 1986); and Katz v. Oak Indus. Inc., 508 A.2d 873, 880 (Del. Ch. 1986).

30. Most commercial contracts are not subject to this complication, because courts can assume (although only roughly) that the contract operates in a competitive market; there is no reason to believe that a party would have agreed to less than what her performance commands on the market. This assumption generally does not hold in the market for unique goods; since sellers can charge more in response to increased demand (which sellers of nonunique goods cannot do), the price to which they once agreed may be lower than the price they can now exact. Alan Schwartz, The Case for Specific Performance, 89 YALE L.J. 271, 281-83 (1979). Courts are therefore reluctant to assess damages in the context of unique goods as well-this is one of the 
employee would not have "reasonably" agreed; some workers might agree to anything. Putting aside the question of whether it is just to enforce higher labor standards for wealthier workers-who would presumably agree to less expansive discretion-courts operating on such a standard would not have any objective criteria by which to evaluate any given exercise of discretion. Even if a judge undertook the expensive task of investigating workers' backgrounds and alternatives, she would still ultimately have to appeal to the psychology of the worker to enforce the equity standard of good faith. The problem is again the joint product of information costs and bargaining-power disparity. The cost of deciphering preferences that are only weakly revealed in express contractual provisions is exacerbated where the bargaining process systematically allows for only limited expression of one party's preferences.

The unreliability of revealed preferences under conditions of inequality may partly explain why courts are unwilling to enforce the contents of company policy manuals, which are treated instead as unilateral expressions of policy. ${ }^{31}$ Although a manual might attract some additional job candidates, it is not usually plausible to assume any single provision conditions the bargain from the point of view of an employee. The same logic applies to the question of whether to hold contracting parties to prevailing community standards of decency regarding compensation or working conditions. The likelihood that parties incorporated those standards of fairness into their expectations recedes as the disparity in bargaining power increases. Community standards are more relevant in commercial contexts where buyers and sellers operate in a competitive market. But in the context of employment, if courts attempt to "determine the likelihood that the contracting parties themselves implicitly or explicitly relied on the relational norms to supply the commitments they could not reduce to written form," the worker will probably be disappointed. ${ }^{32}$

Alternatively, an efficiency standard of good faith might ban inefficient discretionary behavior, or actions that benefit the abuser less than they harm the victim. Efficiency allows more discretion than equity here because it excludes only net losses across both parties with regard to the specific act in question, not any absolute loss being borne by the employee with respect to the whole contract. It is also a procedural notion since if action $X$ produces less gain to $A$ than harm to $B, A$ will not compensate $B$ adequately

\footnotetext{
exceptional circumstances under which the remedy of specific performance is available. Market power consistently complicates contract enforcement.

31. Richard Harrison Winters, Note, Employee Handbooks and Employment-at-Will Contracts, 1985 DUKE L.J. 196.

32. Gillian K. Hadfield, Problematic Relations: Franchising and the Law of Incomplete Contracts, 42 STAN. L. REV. 927,930 (1990).
} 
elsewhere in the contract for the right to $X$; if the issue were negotiated, $A$ would rather forgo the act. ${ }^{33}$

The efficiency standard shares the equity standard's problem of uniquely high enforcement cost in the labor context. The cost, however, has a different source: There is no way to establish who benefits more or less when the units compared are the effort, time, work experience, and money of different people. A court would have to compare goods that are incommensurable. In practice, the court might attempt to calibrate utilities against each other, substituting its business judgment for the firm's to arrive at an independent valuation of employer gain, and projecting the court's own values regarding effort and time onto the worker. Alternately, the court might attempt to attach market prices to the goods.

The market value attached to these incommensurable goods may often fail to capture their "real worth" to various potential entitlement holders, and this would be a standard critique of Kaldor-Hicks efficiency. ${ }^{34}$ But in the labor context, even the market value of particular labor "commodities" is difficult to assess. Although the worker's effort and time have market value, the units at issue in the exercise of discretion are not separable from the bulk of her time and effort, which have already been assigned to the firm, and therefore cannot be priced independently (and accurately). ${ }^{35}$ To assess the price of an extra hour of overtime, then, the court would have to estimate how much more total compensation the worker could obtain on the market for an employment package that includes the $x$ hours she initially expected to sell, plus one. This requires no less of the court than the equity test, for which the court estimates how much she would have demanded for that extra hour ex ante. The estimates of how much she would obtain on the market and how much she would have demanded, or the difference between the market price and the worker's private valuation, only differ if the worker would not have agreed to work at all if required to work an extra

33. If $X$ is bundled with other goods such that it is worthwhile for $A$ to "purchase" $X$, we still would not say that $A$ gave up more than $X$ was worth to $A$ for $X ; A$ would have paid for a bundle that includes $X$. The claim will nevertheless prove false where $A$ incorrectly values $X$ or its cost, or where $A$ simply makes a bad bargain.

34. This could be true because we would pay more to retain many goods than we would pay to obtain them, because those who value a good the most have more limited purchasing power than those who value it less, or because we have cognitive difficulty attaching monetary value to certain goods.

35. I assume a market where labor time is sold in bundles - that is, it is not possible to purchase any number of units of labor from any number of employees. Transaction costs (for example, recruitment, training, and other overhead) and other costs associated with each additional worker render it practically necessary to hire workers who each work some significant number of hours. As a result, an employer who wishes to purchase an hour of overtime cannot turn to a market of job candidates willing to work for just one hour. Although in less extreme cases overtime candidates do face competition from outside work sources (for example, temporary agencies), in general, I assume that there are many cases with no viable market substitute for the proposed overtime that can set prices. 
hour (if her price exceeded the price available on the market). Since it is unrealistic to think that the worker would have refused work rather than work the extra hour without adequate compensation (even no compensation at all), the market reveals little about how much the extra hour is worth to her relative to what she is paid for it. The efficiency interpretation is no more useful to a third party than the equity interpretation.

\section{Substantive Standards}

One possible response to the high enforcement cost of both the equity and efficiency interpretations of good faith in this context is to impose a substantive notion of good faith, which amounts to setting substantive standards for labor contracts (e.g., minimum wage, maximum hours), designed in principle to reflect the outcome of idealized bargaining. Good faith does not lend itself to such a fixed, substantive interpretation because, although certain actions may signal bad intention, the concept of good faith refers to the intent itself, which is conceptually specific to situated actors. The equity standard is customized to the perceived intent of the parties, and even the efficiency standard can be considered a proxy for that to which reasonable parties would have agreed. ${ }^{36}$ But the actual boundaries of reasonableness, approximated in a substantive default rule, cannot be discerned without knowledge of the specific circumstances of the parties. In most cases, any predetermined floor or ceiling will be under- or overinclusive. ${ }^{37}$ Substantive rules are rules of outcome fairness, not procedural reasonableness.

The regulation of outcomes rather than case-specific processes imposes rules that are inappropriately strict or loose in different contexts. This effect would be limited if the rules were defaults; in that case, the standard could be very generous to workers, and employers would bargain around it where appropriate. This would ideally prompt employers to raise issues and make promises, or at least win workers concessions elsewhere in the contract where they specifically agree to waive the default standard. Even then, the provision agreed upon as an alternative to the default standard will be insufficiently tailored given that the parties themselves do not know, ex

36. This parallels Epstein's observation that a finding of substantive unconscionability may be justified on implicit procedural grounds. Richard Epstein, Unconscionability: A Critical Reappraisal, 18 J.L. \& ECON. 293 (1975).

37. This is a standard critique of rules. The equity and efficiency conceptions of good faith are standards, which also have systematic costs. See RICHARD A. POSNER, ECONOMIC ANALYSIS OF LAW 590-95 (5th ed. 1998); Louis Kaplow, Rules Versus Standards: An Economic Analysis, 42 DUKE L.J. 557 (1992). In exploring the particular challenges posed by the duty of good faith, I have argued that the costs of the good faith standard are prohibitively high in individual employment contracts, and are therefore not a viable alternative to rules. 
ante, which rule will serve them best. They do not know, because the relevant information is expensive, if available at all.

The cost of this information leads to substantive standards of good faith that are default only in form. Although they may be designed as penalty defaults, as a result of both high transaction costs and unequal bargaining power, they will not induce employers to reveal information to workers and thereby allow workers to customize their employment packages in response; instead, employers will either deem it too costly to contract around the defaults or they will systematically contract around them. ${ }^{38}$ For example, although the law could stipulate that discretion is used in bad faith if an employer works an employee twelve hours a day unless the employee specifically agreed to work that long, parties presently read discretion into the contract because complete contracts are costly. On the one hand, completeness may be so costly that the parties would rather run the risk of missing mutually beneficial exchanges than attempt to specify those exchanges precisely in advance; requiring that parties provide specific, alternative standards to avoid the effect of substantive good faith standards will then effectively implement mandatory labor standards. Such standards may achieve the distributive goals that motivate the requirement of good faith, but they do so by preempting, not enforcing, it. On the other hand, where it is feasible to specify an alternative, employers with substantial bargaining power will be able to contract systematically around default standards, in which case these defaults will do little work at all.

The ideals of good faith in an individual employment relationship are therefore neither self-enforcing nor readily enforceable by third parties. One policy option is of course to insist on strict court enforcement anyway, hoping that the court will get it right often enough that the benefits in certainty and equity will outweigh the cost of discerning parties' ex ante state of mind or of judging the reasonableness of ex post behavior. But where the courts do not get it right often enough, evoking the duty in court is not just costly to enforce, it is pointless, ${ }^{39}$ and "courts would rather be passive than active when faced with problems they cannot solve." ${ }^{, 40}$

38. See supra note 12 and accompanying text (discussing the inefficacy of default rules in this context).

39. Jason Scott Johnston makes this point with respect to contract renegotiation: "[I]f courts are random or worse at verifying the circumstances surrounding renegotiation, then implication of the good faith obligation cannot help the parties even if they need help." Jason Scott Johnston, Default Rules/Mandatory Principles: A Game Theoretic Analysis of Good Faith and the Cantract Modification Problem, 3 S. CAL. INTERDISC. L.J. 335, 386 (1993). It is telling that bankruptcy law encourages voluntary renegotiation of collective bargaining agreements, instructing trustees and representatives to confer in "good faith." 11 U.S.C. $\S 1113$ (2000). Such an indeterminate mandate is conceivable only because unions possess plausible threats and, therefore, bargaining power. See Gary M. Roberts, Bankruptcy and the Union's Bargain: Equitable Treatment of Collective Bargaining Agreements, 39 STAN. L. REV. 1015, 1036 (1987).

40. Alan Schwartz, Relational Contracts in the Courts: An Analysis of Incomplete Agreements and Judicial Strategies, 21 J. LEGAL STUD. 271, 274 (1992). 
One possibility remains, however-not to courts (at least in the first instance) but to legislatures. This option is to create an institutional framework in which the duty of good faith is rendered self-enforcing. To do this, the institution would correct the asymmetries responsible for skewed contract gaps: disparate bargaining power, high cost of information gathering, and high cost of monitoring. Unions do just that.

\section{UNION ENFORCEMENT OF GOOD FAITH IN COLLECTIVE LABOR CONTRACTS}

The duty of good faith takes a different form in the relations between a union and an employer. Once a union has been recognized by the National Labor Relations Board (NLRB), employers must negotiate in good faith for a collective bargaining agreement that will specify terms and conditions of employment for members of the bargaining unit, usually for one to three years. The duty to bargain in good faith on wages, hours, and other conditions of employment is statutorily explicit, but courts rarely find employers in violation since the obligation "does not compel either party to agree to a proposal or require the making of a concession., ${ }^{, 41}$ Where workers are organized, however, bargaining power enforces the "duty" to bargain in good faith - workers often go on strike at this point. One interpretation of the good faith standard in this case could be that workers' gains in the new contract at least must compensate unions for the cost of organizing - that is, the employer cannot make demands that, by rendering the union an irrational undertaking, demonstrate bad faith in the union itself. No such standard has been adopted, however, not least because it would be impossible to enforce. Legislation that supports unionization without guarantecing its utility to anyone may imply some faith in a union's capacity to make itself useful and to enforce good faith behavior on its own.

The sources of unions' bargaining power are well known. Coordinated action shifts workers' threat point in bargaining. Moreover, the internal decisionmaking procedures of the union allow workers to achieve (to varying degrees of success) congruence in their preferences vis-à-vis the firm through implicit side payments amongst themselves. ${ }^{42}$

The quality of information and monitoring also improve, for two reasons. First, spreading information and monitoring costs over all workers in a unit allows for more research into the firm. Acting through the unionagent also helps depersonalize investigation and monitoring that might otherwise "poison the atmosphere." 43 Second, the problem of asymmetric

41. National Labor Relations Act $\S 8(d), 29$ U.S.C. $\$ 158(d)$ (2000).

42. See B. Douglas Bernheim \& Michael D. Whinston, Common Agency, 54 ECONOMETRICA $923,929(1986)$.

43. Carol M. Rose, Trust in the Mirror of Betrayal, 75 B. U. L. REV. 531, 540 (1995). 
information is alleviated. Workers are more willing to provide information about themselves (their preferences, skills) and their work to the union than to the firm. ${ }^{44}$ Collective bargaining, by pooling workers for contract purposes, allows workers to distinguish themselves honestly from one another. ${ }^{45}$ This is not only more efficient, but also corrects the distributional bias of the prior inefficiency. ${ }^{46}$

Likewise, ex post monitoring costs are lower because workers are able to point out perceived inefficiencies in firm operations with the hope of greater effect and no reprisal. As isolated principals, workers are relegated to mere agent status in their relationships with firms. But contracts can always be seen as bilateral principal-agent frameworks. The "second" dimension of the principal-agent relationship disappears when there is no capability to monitor or enforce. It is not rational for workers to absorb the necessary transaction costs individually. But if they pool for a common agent-to monitor the first agent-economies of scale in research and monitoring will tip the balance.

Just as the union acts as the agent for workers, workers act as agents for the union. In the context of bargaining, they are the strikers; in the context of monitoring, they are the eyes and ears. Enhanced information and monitoring allow unions to make informed demands and enforce them.

The salutary effect of unions on bargaining between workers and employers is not limited to unionized work forces. Fear of third-party enforcement is not an effective deterrent of employer abuse where courts are wary of involvement, but fear of worker organization is effective where union organizers are eager to campaign. As a result, labor law improves bargains for workers even when the law is not invoked. While some courts may be reluctant to extend common-law protection for nonunion workers because statutes now occupy the field, ${ }^{47}$ the possibility of collective

44. It is interesting to note that the customary emphasis on the role of unions in facilitating collusion (bad) rather than in generating economies of scale or correcting informational asymmetries (good) is the reverse of that in the literature on corporate common marketing agents. For an early exception, see B. Douglas Bernheim \& Michael D. Whinston, Common Marketing Agency as a Device for Facilitating Collusion, 16 RAND J. ECON. 269 (1985).

45. Aghion \& Hermalin, supra note 18 , at 402 .

46. Michael Gottesman suggests one reason why individuals may be better bearers of information rights than unions: Confidentiality issues do not arise to the same extent, because most individuals deal with only one employer. Michael H. Gottesman, In Despair, Starting Over: Imagining a Labor Law for Unorganized Workers, 69 CHI.-KENT L. REV. 59,78 (1993). Individuals, however, are in no position to process the vast amounts of information relevant to negotiations; they would be unable to process the limited but still voluminous facts currently made available to unions.

47. One court declined to revise the at-will doctrine to provide a state tort remedy for discharge in breach of the covenant of good faith and fair dealing because "[w]ere we to adopt such a rule, we fear that we would tread perilously close to ... establishing by judicial fiat the benefits which employees can and should get only through collective bargaining agreements or tenure provisions." Wagenseller v. Scottsdale Mem'1 Hosp., 710 P.2d 1025, 1040 (Ariz. 1985). 
bargaining may be an effective substitute for the weak protection common law historically provided.

At the same time, nonunion regimes will discipline union work forces, creating healthy regime competition. ${ }^{48}$ Discipline is also to be expected, however, in a predominantly unionized sector-as long as collective agreements are bargained at the firm level, unions are constrained by interfirm competition. ${ }^{49}$ Strong unions cannot afford to make (successful) unreasonable demands on their employers or systematically protect poor employee performance because workers will bear the costs of their own excess; uncompetitive pay schemes or workplace governance that result in reduced demand for the firms' goods or services will translate into lower wages and layoffs. ${ }^{50}$

Apart from concerns about the ability of unions to strike inefficient bargains with employers, one might worry about unions' exercise of good faith in their duty of fair representation of all union members-collective bargaining may trade one problem of good faith for another. The general agency problem is that unions may promote their own institutional interests, and the interests of union officials, at the expense of those they represent. This problem plagues most principal-agent relationships, and the procedural requirements that the National Labor Relations Act (NLRA) imposes on the union-worker relationship are similar to those used in other spheres, such as political or corporate governance. ${ }^{51}$ The problem of representation is gravest with respect to discrete minorities within the work force, whether identifiable by race, sex, age, or disability. But the problems of good faith raised by the union's function as bargaining agent for these groups are regulated by the NLRB and the courts. First, many minority groups are

48. See Rock \& Wachter, supra note 10, at 1917-18.

49. This is in contrast to pattern bargaining, whereby all employers in a sector agree to follow a union agreement with the largest firms, or industry-wide bargaining, whereby unions and industry-wide employer associations negotiate a single agreement for the sector. In firm-level bargaining, unions bear the costs of their own abuse of power; in pattern or industry-level bargaining, they are able to externalize a large fraction of the costs. Those costs are either borne by the industry as a whole, which becomes uncompetitive internationally; by taxpayers, who subsidize the industry; or by consumers, who pay higher prices. In a classic article, Lars Calmfors and John Drifill argue that unions achieve efficient wage levels when bargaining is either decentralized to the firm level, or centralized (or coordinated) across the economy. The intermediate structure of industry-level bargaining allows for excessive wage push and, as a result, high unemployment. Lars Calmfors \& John Drifill, Bargaining Structure, Corporatism and Macroeconomic Performance, 6 ECON. POL'Y 13 (1988).

50. The actual employment effects of unions are important because if the net effect is very negative, this may offset the perceived benefits of unions, as agents of good faith and otherwise. This empirical question cannot be answered by the brief arguments considered here. In light of the ethical dimension of the gains, however, the most relevant question is not the absolute value of union enforcement of good faith (which cannot be ascertained), but the cost and quality of union enforcement relative to the cost and quality offered by alternative modes of regulation, such as statutory standards.

51. Besides the duty of good faith representation, these include formal elections and disclosure requirements. 
protected by statute. This means that they do not depend on unions alone for the enforcement of their civil rights, and when those rights are violated, they have a more developed body of actionable rights than has ever been conferred by the doctrine of good faith. ${ }^{52}$ Second, other distributional biases conferred by a union are likely to even out over the course of a career. A union that favors older workers in a given bargain probably does so as a result of the structure of the work force, and this means that the bias will be constant over time; younger workers can expect to profit from the bias later. To be sure, these limits to poor union representation do not foreclose all problems, including the classic insider-outsider problem by which unions preserve the interests of their members at the expense of those who are not yet in the labor force, trading growth for wages and security. ${ }^{53}$ The insideroutsider problem, however, is not sustained on a significant scale without active government support; the government must grant unions powers that do not depend on their organizing capacities. Statutes can solve problems created by unions better than those problems that unions themselves address.

Discussing new developments in divorce law, Robert Mnookin and Lewis Kornhauser famously argued for the advantages of private ordering. ${ }^{54}$ Private ordering in that context entailed allowing private parties to negotiate distributive agreements on their own and then obtain a legal stamp of approval; previously, courts tended to treat divorcing couples and their agreements as inherently suspect and insisted on court-directed resolutions. Private ordering is no less advantageous in the employment context, but the parallel must emphasize the state's enabling role in either context. After all, the law does not abandon the parties when it delegates the task of ordering to them; it regulates the background conditions and procedures under which bargaining takes place-for example, default entitlements and the boundaries of legitimate threats. Nevertheless, the law allows the parties to capitalize on their joint informational advantages over the state and to invest in a working relationship. Distributive agreements between individual workers and firms are suspect because disparate bargaining power and high transaction costs render default entitlements and formal procedures inadequate. Even if courts do want to enforce "actual agreements" as they are privately intended, it is too costly to do so: The

52. Nor can the union diminish employees' statutory rights by weakening statutory protections contractually or by monopolizing enforcement through arbitration. "Section 301 preemption" does not extinguish the right of employees to pursue individual rights in court. Lingle v. Norge Div. of Magic Chef, 486 U.S. 399 (1988). Courts may review arbitration decisions inconsistent with explicit public policy, as expressed, for example, in antidiscrimination statutes. See W.R. Grace \& Co. v. Local Union 759, 461 U.S. 757 (1983).

53. This is suspected of German unions. See infra Section V.B.

54. Robert $\mathrm{H}$. Mnookin \& Lewis Kornhauser, Bargaining in the Shadow of the Law: The Case of Divorce, 88 YALE L.J. 950 (1979). 
actual contracts are exceptionally incomplete, and expectations and valuations hard to measure. Facilitating a structure for bargaining that produces nonsuspect, enforceable agreements facilitates private ordering. It alleviates the harsh trade-off between arbitrary and expensive intervention, on the one hand, and rampant bad faith, on the other.

\section{DIVERGENT INSTITUTIONAL RESPONSES}

All advanced industrialized democracies provide for collective bargaining, but union structure and institutional environment vary enormously. As a result, unions in different countries have not fared equally well during the last several decades. But where the scope of collective bargaining has diminished, as in the United States, unions have not left laissez-faire in their wake. Instead, they have reoriented themselves toward the political sphere, where they have won mandatory, untailored background conditions that govern every employment contract. These resemble the "substantive good faith" standards critiqued in Section III.D, with similar problems. In contrast, where collective bargaining continues to regulate most employment relationships, as in Germany, substantive standards play a lesser role.

\section{A. United States}

The institutional response to the impracticality of both judicial and selfenforcement of good faith in employment contracts has varied across legal regimes. In the United States, the Wagner Act of 1935 (the since-amended NLRA) set up the NLRB to regulate union petitions, elections, bargaining, and strikes. Some activities are protected (e.g., striking in response to unfair labor practices) while others are forbidden (e.g., wildcat strikes). ${ }^{55}$ Labor law enumerates mandatory topics of bargaining and, in the absence of impasse, forbids unilateral action by employers in those areas. ${ }^{56}$ Unions are given rights to information pertaining to topics of mandatory bargaining ${ }^{57}$ and represent workers in grievance proceedings under their contracts. In this way, unions pool the costs of information gathering and management monitoring. ${ }^{58}$ The rules are intended to achieve a balance of power between workers and employers that will serve the public interest.

55. 29 U.S.C. $\S 157$ (2000); Prill v. NLRB, 835 F.2d 1481 (D.C. Cir. 1987).

56. 29 U.S.C. $\$ 158$ (d); NLRB v. Katz, 369 U.S. 736,743 (1962).

57. NLRB v. Truitt Mfg. Co., 351 U.S. 149 (1956). Interestingly, the obligation to disclose information was grounded in a duty of good faith: "Good-faith bargaining necessarily requires that claims made by either bargainer should be honest claims... [An important claim requires] some sort of proof of its accuracy." Id. at 152-53.

58. See supra Part IV. 
Unions bargain at the firm level (especially after the demise of pattern bargaining ${ }^{39}$ ) and there is limited interunion cooperation, partly because the national confederation of unions, the AFL-CIO, is primarily a political force. The confederation has little leverage over member unions, not only with respect to traditional union activities like organizing (the recent call to increase the proportion of budgets devoted to organizing went unheeded in several key unions), but even in its area of relative dominance (unions can endorse different political candidates). The distribution of decisionmaking limits the diffusion of industry-level market information that unions could otherwise incorporate into their firm-level agreements. Moreover, as the strength of the labor movement declines, unions can be expected to look to courts with increasing frequency, hoping to compensate for market weakness by capitalizing on laws that reflect their past political strength. The more central litigation becomes to unions' normal bargaining strategy, the fewer the savings in enforcement costs for which unions can claim credit as an institution.

Another consequence of union decline is the rise of what I have described as an institutional alternative-that is, specific default or mandatory rules. ${ }^{60}$ These rules of "substantive good faith" are of increasing importance in the United States. As unions lose their ability to enforce good faith privately, momentum moves to the political sphere both at the level of setting contract terms and of subsequently monitoring compliance. ${ }^{61}$ For example, the Occupational Safety and Health Administration becomes more important as unions are unable to monitor and enforce what were once tailored company-specific standards, and the Pension and Welfare Benefits Administration becomes more important as a watchdog for employer responsibility under the Employee Retirement Income Security Act (ERISA). The Age Discrimination Act of 1967 stems the opportunistic discharge of senior employees whose marginal productivity has declined, and who will soon become eligible for retiree benefits. ${ }^{62} \mathrm{~A}$ range of other antidiscrimination statutes, including the Equal Pay Act of 1963, Title VII of the Civil Rights Act of 1964, and the Americans with Disabilities Act of

59. See supra note 49.

60. See supra Section III.D.

61. For an overview of new employment standards at the state level, see Sid L. Moller, Birth of Contract: Arbitration in the Non-Union Workplace, 50 S.C. L. REV. 183, 191 (1998).

62. Employees are often paid above marginal productivity during their training period, below marginal productivity during their peak productivity years, and then again above productivity later in their careers. Employers have an incentive to discharge in the third stage. The implicit nature of this long-term employment bargain was difficult for courts to enforce under the common law. See Samuel Issacharoff, Contracting for Employment: The Limited Return of the Common Law, 74 TEX. L. REV. 1783, 1788 (1996). The principle of good faith proved too unwieldy an instrument. Id. at 1789; see also Sunstein, supra note 12, at 217 (discussing enforcement of the bargain in the life-cycle model of employment). 
1990, achieve objectives for which unions could otherwise bargain. ${ }^{63}$ The more recent Family and Medical Leave Act and the Worker Adjustment and Retraining Notification Act established by legislative fiat leave-ofabsence and notification rights, respectively, for which unions regularly bargained. ${ }^{64}$

Unions, for their part, have become as much a political as an industrial force. As their influence over individual employers declines, they direct substantial resources toward influencing the legislative and regulatory process ${ }^{65}$ although the extent of the diversion depends on both the economic and political climate. Having once turned to the legislature to replace the common-law framework with statutory procedural protections, unions increasingly turn to the legislature for substantive standards. Given that more constituents are directly affected by substantive than procedural reforms, even legislators sympathetic with unions will affirm this alternative agenda. The adequacy of this alternative to collective bargaining is questionable, however, not only because standards may be too rigid in some cases, but also because they will be enforced inconsistently and belatedly ${ }^{66}$ Observers are wary of arbitration as a low-cost alternative to court enforcement in nonunion workplaces. The disparity in power makes it difficult to discern when consent is truly voluntary, and the employer may not fully abide by the arbitrator's judgment. ${ }^{67}$ Moreover, substantive rules will inevitably fail to foresee market developments that recreate employee risks.

The limits to substantive regulatory standards were dramatically demonstrated when employees at Enron and Lucent Technologies lost substantial retirement income through the decline of company stock. ${ }^{68}$

63. Equal Pay Act, 29 U.S.C. $\$ 206$ (2000); Civil Rights Act of 1964, 42 U.S.C. $\$ \S 2000 \mathrm{e}-1$ to -17 (2000); Americans with Disabilities Act, 42 U.S.C. $\$ \S 12,101-12,213$.

64. 5 U.S.C. $\$ \S 6381-6387$ (2000); 29 U.S.C. $\$ \$ 2101-2109 ; 29$ U.S.C. $\$ \$ 2601-2654$. Unions still bargain over these issues-for example, paid leave or severance pay-because these statutory provisions are minimal. Nonetheless, most workers are protected only by statute.

65. See Steven Greenhouse, A.F.L.-C.I.O. Plans $\$ 40$ Million Political Drive, N.Y. TIMES, Feb. 18, 1999, at A19; Frank Swoboda, Unions Revamp To Rebuild Clout, CHI. SUN-TIMES, Feb. 19,1996 , at 18 .

66. I assess the adequacy of this alternative strictly in terms of the effects on labor contracts. For a discussion of the broader conditions and consequences of politicization of these issues, see Walter Korpi \& Michael Shaley, Strikes, Industrial Relations and Class Conflict in Capitalist Societies, 30 BRIT. J. SOC. 164 (1979) (arguing that certain institutional configurations, but not others, are able to privatize and isolate industrial conflict). But see Adam Przeworski \& Michael Wallerstein, The Structure of Class Conflict in Democratic Capitalist Societies, 76 AM. POL. SCI. REV. 215 (1982) (arguing that the state must activcly adopt certain policies in order to sustain class compromise).

67. See Paul C. Weiler, Governing the Workplace: The Future of Labor and EMPLOYMENT LAW 87, 157 (1990); Stephen J. Ware, Employment Arbitration and Voluntary Consent, 25 HOFSTRA L. REV. 83 (1996).

68. See Alison Grant, Enron, Lucent Workers Urge Investing Care, Cleveland PLAIN DEALER, Apr. 10, 2002, at Cl; Richard A. Oppel, Jr., Employees' Retirement Plan Is a Victim as Enron Tumbles, N.Y. TIMES, Nov. 22, 2001, at A1. 
Although the law places a ten percent limit on the stock that can be invested in employer securities through defined benefit plans or company-directed portfolios, ${ }^{69}$ employees directing their own accounts invest large fractions of their $401(\mathrm{k})$ plans in their employers voluntarily, partly out of loyalty and optimism but partly in response to employer incentives. Where they have the option, workers invest thirty-two percent of plan assets in their employers, and where there is also a matching program, over half of assets are invested in the employer. ${ }^{70}$ Employers have no fiduciary obligation to these employees. Although shareholder protections remain, unlike large institutional investors, individual employees are neither diversified nor informed. Moreover, even shareholder oversight is weakened; employers often offer company securities as $401(\mathrm{k})$ options "precisely as a means of placing large blocks of shares in friendly hands."71

Pensions are also a site of abuse of discretion because ERISA allows employers to terminate a defined benefit plan by purchasing annuities for its employees. These annuities are based on present rather than future expected salary. The inflation premium built into the plan reverts to the employer as surplus, even though workers purchased the pension bargain in return for reduced present wages. While only two million dollars reverted to employers through such a process in 1979 and 1980, in the 1980s twenty billion dollars were removed from plans in this fashion. ${ }^{72}$ Managers and directors decide whether and how to manage a pension plan. Nonunion workers are unable to monitor and protect their investment. Legislators and regulators may attempt to close loopholes, but in so doing, they will further constrain the investment and planning decisions of both firms and their employees.

\section{B. Germany}

The German system of industrial regulation attempts to achieve worker protections almost exclusively through private negotiation. This is striking because only one-third of the work force is actually unionized-but the rate of union membership does not begin to capture the full scope of collective bargaining because employers are more organized than workers. Most workers in unionized industries (i.e., those sectors in which a union exists, even with limited membership) are subject to the agreements through their

69. 29 U.S.C. $\S 1107(\mathrm{a})(2),(\mathrm{b})(2)(\mathrm{B})(\mathrm{ii)}$.

70. Richard A. Oppel, Jr., The Danger in a One-Basket Nest Egg Prompts a Call To Limit Stock, N.Y. TIMES, Dec. 19, 2001, at Cl.

71. Susan J. Stabile, Another Look at 401(k) Plan Investments in Employer Securities, $35 \mathrm{~J}$. MARSHALL L. REV. 539, 546 (2002). In contrast, where unions monitor employee pension plans, they may increase shareholder activism. See Stewart J. Schwab \& Randall S. Thomas, Realigning Corporate Governance: Shareholder Activism by Labor Unions, 96 MICH. L. REV. 1018 (1998).

72. WEILER, supra note 67 , at 166-67. 
employers. ${ }^{73}$ Those agreements are negotiated by industry-level unions and their employer counterparts. Employer associations, along with their related industry associations, facilitate the compilation of the industry-wide data that are less accessible in U.S. bargaining.

A second layer of worker representation exists in the form of codetermination (Mitbestimmung), which guarantees worker representation on firm supervisory boards and works councils, which help govern at the workplace level. The Co-Determination Act of $1976^{74}$ provides for parity between employees and shareholders on the supervisory boards of stock companies that employ over 2000 persons while the 1952 Works Constitution $\mathrm{Act}^{75}$ provides for one-third representation in smaller firms. An election rule excluding unions with less than five percent of the vote ensures dominance by unions associated with the DGB (German Trade Union Confederation). Their plant-level governance through works councils, often supplemented by shop-steward committees, helps unions to understand the priorities of their local memberships when they bargain, and once the bargain is struck, plant-level implementation is informed by the intentions of the original bargain. ${ }^{76}$ Though these industry-level unions dominate collective bargaining, the DGB plays a servient coordinating function across sectors after the metalworkers' IG Metall, and more recently and to a lesser extent, the public sector workers' ÖTV, set the trend in each round of wage negotiations. The DGB's links to national and plantlevel decisionmaking raise the quality of economy-wide information available to all parties in bargaining.

German unions have not shifted their efforts to the political sphere. Although the DGB is not as apolitical as its official independent status suggests, it has no financial or campaign ties with the Social Democratic Party and issues no endorsements. This partly reflects a difference between the Republican Party and the Christian Democratic Union; the latter formally incorporates both labor and corporate interests. Although, given its size, the German labor movement is a latent political force, it continues to pursue its interests through primarily private channels. For example, there is

73. Industry-wide bargains in the manufacturing, banking, and insurance sectors cover eighty percent of firms and ninety percent of employees. European Found. for the Improvement of Living \& Working Conditions, Germany: Arbeitgeberverband (Employers' Association), at http://www.eurofound.ie/emire/GERMANY/EMPLOYERSASSOCIATION-DE.html (last visited Mar. 13, 2003).

74. Gesetz über die Mitbestimmung der Arbeitnehmer (Mitbestimmungsgesetz-Mitbest $G$ ), v. 4.5.1976 (BGB1. I S.1153).

75. Betriebverfassungsgesetz 1952 (BetrVG 1952), v. 11.10.1952 (BGB1. I S.681).

76. For example, provisions that allow wage drift-extra pay over the base industry-wide wage rate, bargained at the plant level-are delicate compromises between those seeking wage compression across skill levels and those who stand to benefit from increased wage dispersion. The political viability of these provisions hinges on the union's ability to monitor their implementation at the plant level. 
no national minimum wage; in those exceptional sectors where the government imposes a statutory minimum, the Ministry of Labor issues an order that extends an existing collective bargaining agreement that already applies to more than fifty percent of the employees in the sector to those not covered by it (Allgemeinverbindlichkeitserklärung). ${ }^{77}$ In contrast, the American minimum wage and overtime rules are specified by law, ${ }^{78}$ and are the subject of periodic political controversy. The reasons for comparative political noninterference in Germany relate not only to the continued strength of organized labor, but also to the culture of independence suggested by the constitutional principle of Tarifautonomie, which recognizes the right of collective industrial organizations to regulate terms and conditions of employment free of state interference. ${ }^{79}$ This constitutional protection is meaningful partly because the renowned stagnancy and predictability of government policy that results from highly consensual processes allows organizations to develop long-term expectations and relationships. It does this just because it limits the possibility of state interference even when desired by powerful social groups, or even by powerful state actors. Instead, the state empowers societal organizations to coordinate privately what other states might legislate. Hence, Wolfgang Streeck's reference to the "enabling state." Unions are careful to guard their territory against overtly political intrusion: When Social Democrat Oskar Lafontaine suggested during the 1988 public sector negotiations that salaried civil servants go without the pay compensation for progressive work time reduction that others had received, and that the savings be used to hire additional employees, union leaders objected not only because the proposal contradicted their full compensation strategy but also because Lafontaine had violated "labor's taboo against mobilizing external public support for results unwanted by unions presently engaged in negotiations." $\$ 1$

The German and American cases suggest that although unions may be seen as general alternatives to substantive rules, the choice is not all or nothing. The law of collective bargaining serves as a substitute for direct intervention in the form of mandatory standards and administrative enforcement only to the extent that it helps unions assemble information, monitor employers, and bargain on equal footing-those functions that enable unions to enforce privately incomplete employment contracts. The

77. Tarifvertragsgesetz (TFG), v. 25.8.1969 (BGBl. I S.1323).

78. 29 U.S.C. $\S \S 206-207(2000)$.

79. GRUNDGESETZ [GG] art. $9, \S 3$.

80. Wolfgang Streeck, German Capitalism: Does It Exist? Can It Survive?, in PoLITICAL ECONOMY OF MODERN CAPITALISM 33, 38 (Colin Crouch \& Wolfgang Streeck eds., 1997).

81. Peter Swenson, Labor and the Limits of the Welfare State: The Politics of Intraclass Conflict and Cross-Class Alliances in Sweden and West Germany, 23 COMP. POL. 379, 388 (1991). 
NLRA supports these union functions to a lesser extent than does the German system. As a result, the American legislative and executive branches offer more direct assistance to private parties in the form of mandatory rules and administrative enforcement. In assessing the price we pay for union enforcement of good faith, we must take into consideration the cost of its alternatives.

\section{CONCLUSION}

The merits and demerits of competing forms of collective bargaining, as well as the general principle of collective bargaining itself, extend well beyond the question of good faith. In addition to questions of aggregate long-term economic and distributional consequences, there is the problem of managing the diverse interests of a heterogeneous work force, and the risk that one group (e.g., high-skilled or elderly workers) will capture the leadership of the union and pervert its purposes. My aim here has been to identify one function that labor law fulfills, not to assess whether the benefits of collective action ultimately outweigh its pitfalls in this context.

Statutory labor law is seen as alien to the common law. This approach is lamented by some ${ }^{82}$ and celebrated by others, but is in any case blind to the internal dilemmas created by common-law principles of contract law, which require a statutory response, whether procedural or substantive. The presumption that the common law offers a coherent and viable alternative (whether or not desirable) to the statutory regulation of the employment relationship is consistent with the fact that limits to traditional common-law employment rules, such as at-will discharge, are required to have exogenous backing. ${ }^{83}$ In fact, unabashedly proemployer common-law employment rules were always in tension with other commitments of the common law, and this is reflected in the tortuous treatment of good faith. ${ }^{84}$

82. For example, Posner cites the NLRA as an example of a redistributive statute that is the product of special interest rent-seeking, in contrast to the (relatively) efficient common law. POSNER, supra note 37 , at 569

83. See, e.g., Pierce v. Ortho Pharm. Corp., 417 A.2d 505, 511 (N.J. 1980) (holding that a specific expression of public policy is requircd for an exception to the at-will discharge rule); Woolley v. Hoffman-La Roche, Inc., 491 A.2d 1257, 1260-61 (N.J. 1985) (applying Pierce and holding that the NLRA implies that the employer's right of discharge cannot be used as a means of oppression). Although Keith Hylton also identifies minimum terms in the common-law doctrine that arise from "fundamental rights" respected by common law, these rights of liberty and unrestrained trade also have constitutional and statutory bases, respectively. Keith N. Hylton, $A$ Theory of Minimum Contract Terms, with Implications for Labor Law, 74 TEX. L. REV. 1741, 1755 (1996). While scholars previously also thought of interpretive gap-filling principles (like good faith) as derivative from principles and policy external to the common law, these rules are now seen to serve contractual intent as well as efficicncy, at least where they are "default" rather than "immutable." See Randy E. Barnett, The Sound of Silence: Default Rules and Contractual Consent, 78 VA. L. REV. 821 (1992).

84. See supra note 23. 
Legal economists who deem it dangerous (that is, inefficient) to assign meaningful duties under the principle of good faith in incomplete contracts are effectively rejecting a common-law principle.

The idea of artificially inducing good faith, unlike punishing bad faith, may appear to empty the concept of its normative force. But the doctrine of good faith confirms that the law does not seek to enforce moral motivation, a purpose unbecoming of a liberal state. It seeks only to discourage inefficient and inequitable outcomes. This indifference to the well-being of contracting parties' souls is inevitable because in the public sphere good faith is scarce where opposing bargaining power is absent as a background condition. Employment relationships are not the only example; tenantlandlord and franchisee-franchiser relationships are also fraught with inequality and opportunism. Collective organization is one response to the challenge of enforcing the amoral notion of good faith that is of import to the common law. 